\title{
SELF-EFFICACY AND STUDENT ACHIEVEMENT FOR ENHANCING CAREER READINESS: THE MEDIATION OF CAREER MATURITY
}

\author{
Mar'atus Sholikah ${ }^{1, *}$, Muhyadi ${ }^{2}$, Setyabudi Indartono ${ }^{3}$, Olzhas B. Kenzhaliyev ${ }^{4}$, \\ Gulzhaina K. Kassymova ${ }^{5}$ \\ 1,2,3 Faculty of Economics, Universitas Negeri Yogyakarta, Karangmalang, Yogyakarta 55281, Indonesia \\ ${ }^{4,5}$ Institute of Metallurgy and Ore Beneficiation, Satbayev University, 22a Satpaev str. 050013, Almaty, Kazakhstan \\ ${ }^{4}$ Kazakh-British Technical University, Almaty, Tole bi street, 59, Kazakhstan \\ ${ }^{5}$ Abai Kazakh National Pedagogical University, Dostyk ave, 13, 050010 Almaty, Kazakhstan \\ E-mail: maratussholikah.2019@student.uny.ac.id* \\ *Corresponding Author
}

\begin{abstract}
Increasingly dynamic and volatile employment trends and the rapid development of the globalization era resulted in the transformation of the world of work to be faster, diverse and challenging to predict. Therefore, individuals are encouraged to have a flexible attitude to adapt and work according to their current career development. The purpose of this study was to determine the effect of self-efficacy and academic achievement on career readiness outside the profession through career maturity as a mediator. The survey method with a quantitative approach was applied in this study using a sample of 80 students. This study selected the sample based on purposive sampling on all Office Administration students of the State University of Semarang. Data analysis performed using Smart PLS 3.0. This study tested the proposed model through two aspects: measurement and structural models. This study found that self-efficacy and career maturity positively and significantly affected career readiness outside the profession. Academic achievement, in this case, also affects career readiness, but not considerably. The role of career maturity as mediation has an effect on self-efficacy on career readiness partially. Thus, it can conclude that self-efficacy influences career readiness. These findings make an essential contribution for lecturers and institutions to pay more attention to student career readiness so that their opportunities as university graduates to be accepted into the world of work can run smoothly.
\end{abstract}

Keywords: career maturity, career readiness, self-efficacy, student achievement

\section{INTRODUCTION}

Career readiness outside the profession defines a significant development for adolescents considering the role of preparedness in enhancing personal growth, social adaptation, and welfare for them in career developmental theories, readiness, or awareness of the choices will also influence the information on the world of work. In this sense, planning that supports career choices is a significant predictor of success in career choices and the transition from school and campus to work. In general, Crites explained that career theory focuses on two factors that influence educational decisions and the application of career choices, namely competency factors and attitude factors [1].

Competency factors (often referred to as cognitive domains) in choosing or making career decisions consist of self-knowledge, occupational information, goal selection, planning, and problem-solving. This opinion is in line with the social cognitive approach theory, which states that adolescent competence plays an essential role in determining their life path. Attitude factors emphasize the development of positive attitudes towards career planning and exploration. This attitude factor is also known as non-cognitive factors or often referred to as the affective domain. This affective domain includes achievement goals, self-efficacy, and academic outcomes [2]. In addition to competency factors that guarantee individual success in career planning, positive attitude factors also play an essential role in one's career success [3]. These competency factors and positive attitude factors are complementary components in career planning and exploration. Thus, as a result, competence and positive attitudes are used to facilitate career choices. 
This study examines the direct and indirect effects of career choice decisions on students' competency and attitude factors. The competency component of the career preparation process in this study is career choice readiness outside the profession. The self-efficacy concept emphasizes the degree of self-confidence of a person to successfully engage in tasks related to career choices [4]. Generally, the developmental theory accepts that self-efficacy plays an essential role in determining attitude and career preparation [5]. Using grade point average (GPA) is considered a reflection of academic success, pedagogical goals achievement to measure academic achievement. In line with York et al., [6] the most frequently used indicator of academic success is academic achievement or, more concretely, GPA. Although academic achievement is a GPA or value, this cognitive domain variable involves knowledge and intellectual skill development [2], [7].

Previous research found that the social cognitive career theory (SCCT) reveals a correlation between the main variables in preparing career choices, and the results are positively related. These variables consist of self-efficacy beliefs, individual performance or academic achievement, and career persistence. Low self-efficacy is related to a person's hesitation in preparing for a career and fear of commitment. Self-efficacy affects attitude in career decision-making and career maturity. This finding is corroborated by Koivisto et al. 's research, which also found that the individual's ability to determine subsequent career decisions is related to commitment, a component of successful academic achievement [8]. Several previous researchers have found that readiness to choose a career has a beneficial influence on the future [9].

Therefore, this study adds a career maturity variable to mediate between variables so that the results obtained to explore the direct and indirect effects of self-efficacy and academic achievement on career readiness outside the profession with career maturity as an intervening variable. The novelty of this research lies in the data analysis tool that is using SmartPLS. Meanwhile, previous research also has not conducted further research related to the variables studied in this study. Thus, this study aims to determine the effect of self-efficacy and academic achievement in increasing job readiness with career maturity mediation.

\section{METHOD}

The method used should be accompanied by references. Data analysis techniques emphasized literature items obtained from literature reviews and expert opinions. Data regarding self-efficacy, academic achievement, career readiness, and career maturity were collected through a questionnaire using an online survey model via a google form. This research sample is active students in the Office Administration Education Study Program at Semarang State University. The data collection process lasted for two months, in which the respondents were selected based on the purposive sampling technique. Respondents who received the questionnaire were those who volunteered with pre-stated consent. The questionnaire questions were rated based on a Likert scale (1: strongly disagree-5: strongly agree). We distributed to all respondents and received as many as 80 return questionnaires, all of which were valid for further analysis. Table 1 shows the demographic data results. Respondents totaling 80 people consisted of $18.75 \%$ male and $81.25 \%$ female; the respondents' mean age was 21 years, and most do not have work experience.

Table 1. Demographic Data of Respondents

\begin{tabular}{ccc}
\hline Attribute & Classification & $\%$ \\
\hline Gender & Male & 18.75 \\
& Female & 81.25 \\
Age (year) & 20 & 27.50 \\
& 21 & 61.25 \\
& 22 & 10.00 \\
Experience in & 23 & 1.25 \\
industrial work & Yes & 40.00 \\
\hline
\end{tabular}

There are two parts in the questionnaire design for data collection: the introductory 
section and the questionnaire questions. The preceding paragraph includes a series of helpful items for obtaining participant demographic data, such as gender, age, and work experience. Meanwhile, part two is arranged based on a Likert scale ranging from 1 to 5 (1: strongly disagree, 5: strongly agree). It is developing to measure and ensure the model's construct based on the literature, adjusted to the object research.

Tabel 2. Measuring Dependent Construct

\begin{tabular}{|c|c|c|c|}
\hline Constructs & & Indicators & Source \\
\hline \multirow{4}{*}{$\begin{array}{l}\text { Career } \\
\text { readiness }\end{array}$} & REA1 & Crystallizing & [10] \\
\hline & REA2 & $\begin{array}{c}\text { Exploring } \\
\text { occupations }\end{array}$ & \\
\hline & REA3 & Deciding & \\
\hline & REA4 & Preparing & \\
\hline \multirow{4}{*}{$\begin{array}{l}\text { Career } \\
\text { maturity }\end{array}$} & CAR1 & Concern & [3] \\
\hline & CAR2 & Control & \\
\hline & CAR3 & Curiosity & \\
\hline & CAR4 & Confidence & \\
\hline
\end{tabular}

Table 3. Measuring Independent Construct

\begin{tabular}{|c|c|c|c|}
\hline Constructs & & Indicators & Source \\
\hline \multirow[t]{5}{*}{ Self-efficacy } & SEF1 & Self-appraisal & [11] \\
\hline & SEF2 & $\begin{array}{l}\text { Occupational } \\
\text { information }\end{array}$ & \\
\hline & SEF3 & Goal selection & \\
\hline & SEF4 & Planning & \\
\hline & SEF5 & $\begin{array}{l}\text { Problem- } \\
\text { solving }\end{array}$ & \\
\hline $\begin{array}{c}\text { Academic } \\
\text { achievement }\end{array}$ & GPA.1 & $\begin{array}{l}\text { Grade point } \\
\text { average }\end{array}$ & $\begin{array}{c}{[2],[6],} \\
{[12]}\end{array}$ \\
\hline
\end{tabular}

The number of variables tested in this study consisted of four variables, namely selfefficacy (SEF), academic achievement (GPA), career readiness outside the profession (REA), and career maturity (CAR), which formulated the following hypotheses.

H1: Self-efficacy directly affects career readiness outside the profession

$\mathrm{H} 2$ : Academic achievement directly affects career readiness outside the profession

H3: Career maturity directly affects career readiness outside the profession

H4: Self-efficacy affects career readiness outside the job through career maturity Academic achievement affects career

H5: readiness outside the job through career maturity
The data in this study were analyzed using the Partial Least Squares Structural Equation Model (PLS-SEM). This analysis aims to test the model. This methodology adopts a structure based on a variant of the structural equation model approach for multivariate analysis, which recognizes that assumptions are more flexible and offer more accurate testing of model hypotheses [13], [14].

There are two main advantages offered by the PLS-SEM technique compared to other covariance analysis-based structural equation models. The first advantage is that it allows the inclusion of the variables modeled as formative composites and each indicator's loading factor value. The second advantage is that this approach is oriented towards the target variable and measures its antecedents' predictive strength [15]. Therefore, PLS-SEM is considered an adequate methodology. This approach's analysis includes the measurement model testing stage and the hypothesis assessment stage [15]. In testing the measurement model, the variables' validity and reliability need to determine in advance. Meanwhile, the hypothesis assessment explains the variance and predictive power of the model. The research analysis uses SmartPLS 3.2.5 software [16], [17].

\section{RESULTS AND DISCUSSION}

Table 4 presents the results of the descriptive analysis of the variables in the study. The maximum value obtained from the selfefficacy variable is 80 ; minimum value 32 ; mean value 64.30; and a standard deviation of 8,372 . Furthermore, the academic achievement variable has a maximum of 3.96, a minimum amount of 3.00 , a mean value of 3.6925 , and a standard deviation of 0.15747 . Meanwhile, the career readiness variable has a maximum amount of 50, a minimum score of 19 , a mean of 42.26 , and a standard deviation of 5.269. The career maturity variable has a maximum value of 75 , a minimum amount of 29 , a mean of 64.51 , and a standard deviation of 8.823 . 
Table 4. Descriptive Statistics for the Path Analysis Model Variables

\begin{tabular}{cccccc}
\hline Variable & $\mathrm{N}$ & Min. & Max. & $\bar{x}$ & SD \\
\hline Career & 80 & 19.00 & 50.00 & 42.26 & 5.269 \\
readiness & & & & & \\
Self-efficacy & 80 & 32.00 & 80.00 & 64.30 & 8.372 \\
Academic & 80 & 3.00 & 3.96 & 3.69 & 0.157 \\
$\begin{array}{c}\text { Achievement } \\
\text { Career }\end{array}$ & 80 & 29.00 & 75.00 & 64.51 & 8.823 \\
maturity & & & & & \\
\hline
\end{tabular}

This study used the Split-half coefficient and Cronbach Alpha Coefficient to ensure instrument consistency and stability with SPSS software version 24. If Split-half and Cronbach's Alpha is higher than 0.70 , it shows reliability [18], [19]. As shown in Table 5, both have values higher than 0.70, indicating that the instrument has a high value.

Since the instruments used do not have a strong theoretical foundation, research should test their structural validity. The questionnaire contains four latent variables, and this study conducts an exploration factor of each analyst. Further analysis, the KMO (Kaiser Meyer Olkin Measure of Sampling) value of all dimensions is more significant than 0.70 , and the significance is less than 0.01 ; it means that the researcher can use the data for analysis. Long [20] supported that if the cumulative percentage exceeds $60 \%$, then the extracted factor represents all variables.

The KMO (Kaiser Meyer Olkin Measure of Sampling) values signify, and cumulative rates of each Table 5. When performing exploration factor analysis, loading factors below 0.40 should be removed [21]. Thus, Table 6 shows the loading factor value on each variable. The next step is the analysis of confirmatory factors. The purpose of the measurement model assessment is to confirm the construct's reliability and validity [18].

Table 5. Reliability and Validity $(n=30)$

\begin{tabular}{cccccc}
\hline Variable & $\alpha$ & $\begin{array}{c}\text { Split- } \\
\text { half }\end{array}$ & KMO & Sig. & $\begin{array}{c}\text { Cumulative } \\
\%\end{array}$ \\
\hline REA & 0.846 & 0.768 & 0.612 & 0.000 & 96.6 \\
SEF & 0.943 & 0.950 & 0.622 & 0.000 & 94.3 \\
CAR & 0.949 & 0.846 & 0.660 & 0.000 & 86.4 \\
\hline
\end{tabular}

Table 6a. Loading Factor Value $(n=30)$

\begin{tabular}{|c|c|c|c|c|}
\hline \multirow[t]{2}{*}{ Items } & \multicolumn{4}{|c|}{ Component } \\
\hline & CAR & GPA & REA & SEF \\
\hline CAR1.2 & 0.652 & & & \\
\hline CAR1.4 & 0.828 & & & \\
\hline CAR1.5 & 0.804 & & & \\
\hline CAR1.6 & 0.787 & & & \\
\hline CAR2.1 & 0.870 & & & \\
\hline CAR2.2 & 0.748 & & & \\
\hline CAR2.4 & 0.827 & & & \\
\hline CAR2.5 & 0.788 & & & \\
\hline CAR3.1 & 0.829 & & & \\
\hline CAR3.2 & 0.925 & & & \\
\hline CAR3.3 & 0.871 & & & \\
\hline CAR3.4 & 0.863 & & & \\
\hline CAR3.5 & 0.795 & & & \\
\hline CAR4.1 & 0.634 & & & \\
\hline CAR4.2 & 0.857 & & & \\
\hline CAR4.3 & 0.909 & & & \\
\hline CAR4.4 & 0.844 & & & \\
\hline CAR4.5 & 0.844 & & & \\
\hline GPA & & 1.000 & & \\
\hline
\end{tabular}

Table 6b. Loading Factor Value $(n=30)$

\begin{tabular}{|c|c|c|c|c|}
\hline \multirow[t]{2}{*}{ Items } & \multicolumn{4}{|c|}{ Component } \\
\hline & CAR & GPA & REA & SEF \\
\hline REA1.2 & & & 0.790 & \\
\hline REA1.4 & & & 0.835 & \\
\hline REA1.5 & & & 0.807 & \\
\hline REA1.6 & & & 0.751 & \\
\hline REA2.1 & & & 0.747 & \\
\hline REA2.2 & & & 0.705 & \\
\hline REA2.3 & & & 0.773 & \\
\hline REA3.1 & & & 0.701 & \\
\hline REA3.2 & & & 0.860 & \\
\hline REA3.3 & & & 0.806 & \\
\hline REA4.2 & & & 0.781 & \\
\hline REA4.3 & & & 0.828 & \\
\hline SEF1.1 & & & & 0.766 \\
\hline SEF1.2 & & & & 0.813 \\
\hline SEF1.4 & & & & 0.778 \\
\hline SEF1.5 & & & & 0.867 \\
\hline SEF2.2 & & & & 0.919 \\
\hline SEF2.3 & & & & 0.920 \\
\hline SEF2.4 & & & & 0.866 \\
\hline SEF2.5 & & & & 0.871 \\
\hline SEF3.2 & & & & 0.870 \\
\hline SEF3.3 & & & & 0.872 \\
\hline SEF3.4 & & & & 0.696 \\
\hline SEF4.1 & & & & 0.708 \\
\hline SEF4.3 & & & & 0.834 \\
\hline SEF4.5 & & & & 0.637 \\
\hline SEF5.1 & & & & 0.726 \\
\hline SEF5.2 & & & & 0.837 \\
\hline SEF5.3 & & & & 0.753 \\
\hline
\end{tabular}


As suggested, the reliability analysis using Cronbach's Alpha and composite reliability values. Cronbach's Alpha aims to measure internal consistency reliability. Cronbach's Alpha range is 0.880 to 1,000 , and the composite reliability range in the model is 0.905 to 1,000 , greater than 0.70 [18]. To confirm convergent validity, researchers took into account the outer loadings of the indicator, as well as average variance reliability (AVE) [18]. The outer loading value ranges from 0.714 to 1,000 , as shown in Figure 1. If the value of the outer loading is below 0.70 , they must be removed [18]. According to Brataningrum \& Saptono [22], if the outer loading value is between 0.50 0.70 , the indicator does not need to be removed if it has an AVE value higher than 0.50.

The average variance extracted (AVE) is a measure for building convergent validity [18]. Should AVE be higher than 0.50 , considered that the construct is valid [23]. For more details, Table 7 displays the AVE value of each construct greater than 0.50 , indicating that the model's convergence validity is good. To know discriminant validity, the researcher can also use the Fornell-Larcker criteria. As shown in Table 7, each variable's AVE square root value is higher than the coefficient of another variable. Therefore, it indicates that the tool has sufficient discrete validity [18].

In addition to using the Fornell-Larcker criteria, the researcher can also operate from heterotrait-monotrait ratio (HTMT) [18]. According to the HTMT value, the confirmed discriminant validity indicated that the HTMT value was below the acceptable threshold value $\leq$ of 0.90 (Table 6). After determining the measurement model's reliability and validity, the next step is to analyze the structural model to check the predicted hypothesis's significance.

This study uses Bootsrap SmartPLS 3.0 to test the significance of the path coefficient and its effectiveness according to the $\mathrm{t}$ value. If $\mathrm{t}$ greater than 1.96 means significant. Otherwise, if $t$ less than 1.96 means insignificant [18]. Table 8 shows that the GPA path coefficient $\rightarrow$ REA 0.016 , the $\mathrm{T}$ value is 0.292 , smaller than 1.96 , and the $p$-value is 0.771 , which is greater than 0.05 , and cannot pass the significance test. The remaining path coefficient passes the significance test, as shown in Figure 2. The amount of direct and indirect influence is the total effect. The effect of the variable model shows in Table 8.

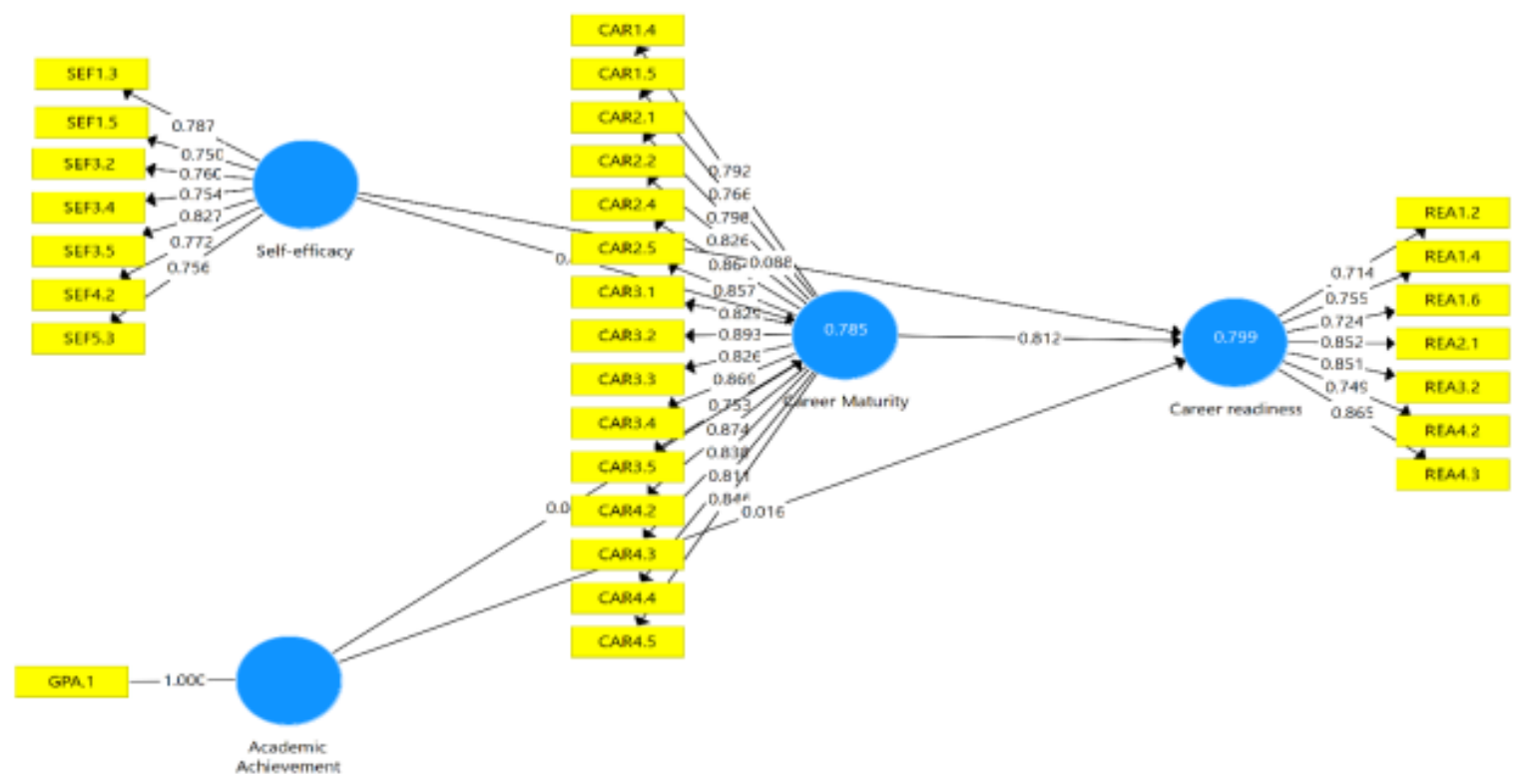

Figure 1. Value Outer Loading Model of Student Career Readiness 
Table 7. Reliability and Convergent Validity Analysis $(\mathrm{n}=110)$

\begin{tabular}{|c|c|c|c|c|c|c|c|c|c|c|c|}
\hline \multirow[t]{2}{*}{ Variables } & \multirow[t]{2}{*}{$\alpha$} & \multirow[t]{2}{*}{$\mathrm{CR}$} & \multirow[t]{2}{*}{ AVE } & \multicolumn{4}{|c|}{ Fornell-Larcker } & \multicolumn{4}{|c|}{ HTMT } \\
\hline & & & & GPA & CAR & REA & SEF & GPA & CAR & REA & SEF \\
\hline GPA & 1.000 & 1.000 & 1.000 & 1.000 & & & & & & & \\
\hline CAR & 0.953 & 0.965 & 0.874 & 0.178 & 0.935 & & & 0.182 & & & \\
\hline REA & 0.907 & 0.933 & 0.777 & 0.189 & 0.903 & 0.882 & & 0.196 & 0.791 & & \\
\hline SEF & 0.880 & 0.905 & 0.657 & 0.145 & 0.853 & 0.786 & 0.810 & 0.176 & 0.390 & 0.878 & \\
\hline
\end{tabular}

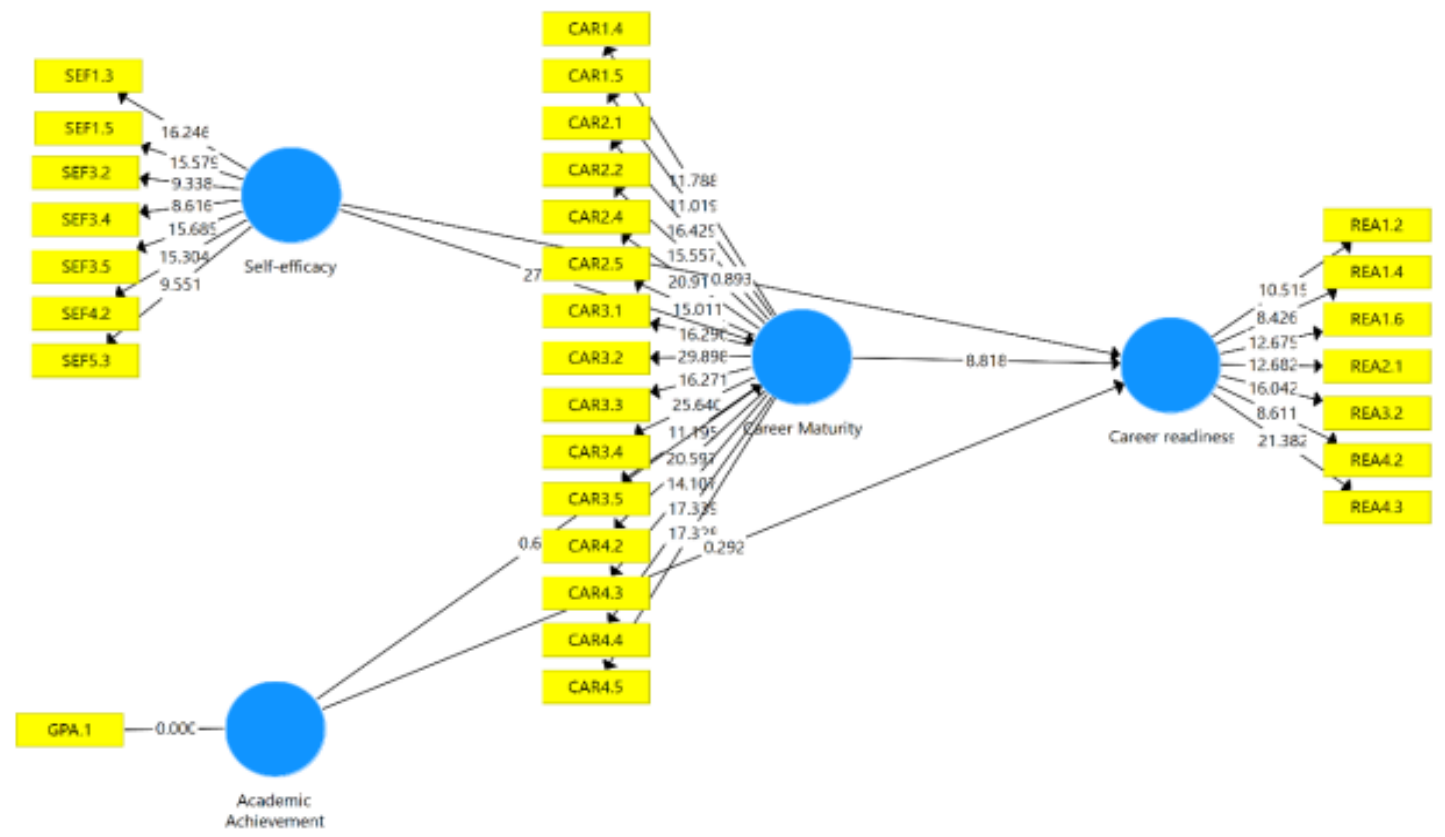

Figure 2. Path and Significant Coefficient in Structural Model Assessment ( $\mathrm{n}=110)$

Table 8. Effect of the Model

\begin{tabular}{cccc}
\hline Path & $\begin{array}{c}\text { Direct } \\
\text { effect }\end{array}$ & $\begin{array}{c}\text { Indirect } \\
\text { effect }\end{array}$ & $\begin{array}{c}\text { Total } \\
\text { effect }\end{array}$ \\
\hline $\mathrm{SEF} \rightarrow \mathrm{REA}$ & 0.801 & 0.00 & 0.801 \\
$\mathrm{SEF} \rightarrow \mathrm{CAR}$ & 0.878 & 0.000 & 0.878 \\
$\mathrm{GPA} \rightarrow \mathrm{REA}$ & 0.016 & 0.000 & 0.051 \\
$\mathrm{GPA} \rightarrow \mathrm{CAR}$ & 0.043 & 0.000 & 0.043 \\
$\mathrm{CAR} \rightarrow \mathrm{REA}$ & 0.812 & 0.000 & 0.000 \\
$\mathrm{SEF} \rightarrow \mathrm{CAR} \rightarrow \mathrm{REA}$ & 0.000 & 0.714 & 0.714 \\
$\mathrm{GPA} \rightarrow \mathrm{CAR} \rightarrow \mathrm{REA}$ & 0.000 & 0.035 & 0.035 \\
\hline
\end{tabular}

The value of the determination coefficient is a standard based on the structural model in comparison. In other words, the researcher can use cumulative influence on independent variables on dependent variables. According to Cohen, 0.26 is substantial, 0.13 moderate, and 0.02 weak. Hair et al. state that the value of R2 0.20 is considered high in social disciplines [18]. Table 9 shows a summary of the R-square values for each of the latent variables. As presented in Table 9, the amount of student career maturity is 0.731 , which indicates that the variance value of career maturity is explained by self-efficacy and academic achievement, namely by a percentage of $73.1 \%$.

In contrast, the rest is explained by other variables not examined in this research model. The R-square value for the career readiness variable obtained is 0.817 , which indicates that self-efficacy and student achievement can influence career readiness by $81.7 \%$. In contrast, other variables outside the research model explain the rest. Stone-Geisser is a founder of predictive relevance $\left(\mathrm{Q}^{2}\right)$ application. The $\mathrm{Q}^{2}$ value of more than 0 indicates that an independent variable predicts relevance for dependent variables [18]. Table 9 displays the $\mathrm{Q}^{2}$ value. All predictive relevance values are more significant than zero; this means that the model is highly predictive.

Table 9. The Results of R-Square

\begin{tabular}{cccc}
\hline Variables & $\mathrm{R}^{2}$ & $\mathrm{R}^{2}$ Adjusted & $\mathrm{Q}^{2}$ \\
\hline CAR & 0.731 & 0.724 & 0.642 \\
REA & 0.817 & 0.810 & 0.337 \\
\hline
\end{tabular}


The goodness of Fit (GoF) aims as a diagnostic tool to assess the suitability of PLSSEM models. GoF is measured using the geometric average values of the extracted variance average and the $\mathrm{R}^{2}$ value and calculated using the following equation $G o F=\sqrt{A V E \times R^{2}}$ [24]. When the GoF value is more significant than 0.36, the model matches; when GoF 0.25, then the model is quite fitting; when GoF is less than 0.10 , it does not match [25]. For the model used in this study, the GoF value was 0.58 , indicating a good model match. However, Henseler et al. show that GoF does not represent PLS-SEM conformity criteria [26]. Hair et al. suggested that researchers should not use GoF as a measure [18]. Henseler et al. [26] recommend Standardized Root Mean Square Residual (SRMR) as a good conformity measure for PLSSEM to avoid model specification errors. A value of less than 0.08 is considered suitable. In this study, the SRMR value was 0.068 , less than 0.08 . So, the fit model is also good with the SRMR index.

The purpose of this study was to examine the direct and indirect effects of self-efficacy and academic achievement on career readiness outside the teaching profession through career maturity. As has been hypothesized, this finding indicates that self-efficacy and career maturity positively and significantly affect career readiness outside the teaching profession. Supporting by the p-values of 0.032 and 0.000 , which are less than 0.050 , and the estimated values are 0.088 and 0.812 . Thus, hypothesis 1 in this study is supported. The amount of the selfefficacy variable's direct influence on student career activities is 0.088 and 0.812 .

This finding is consistent with previous research that was influenced by self-efficacy [27]-[29]. Supported by Jones et al., Ko \& Kim, and Parikh-Foxx et al. [30]-[32]increasing selfefficacy in career decision making is essential considering that self-efficacy is a behavior to prepare for an influential career. Considering social cognitive theory, students' career readiness in making career choices results from career exploration motivation. In line with hypothesis 3, career maturity, as we know, increases readiness in career planning. In line with social cognitive theory, this reinforces students' commitment to applying their skills, which complements student readiness's influence on other career choice behaviors [33].

Previous research has found that someone who has a career maturity will tend to be more ready to work as planned [34]-[37]. Caballero et al. found that career maturity makes a significant contribution to career readiness because someone who has career maturity will improve his quality and abilities for the future career [38].

In contrast to hypothesis 2 in this study, academic achievement has no significant effect on career readiness, as evidenced by a p-value of 0.771 less than 0.05 and an estimated value of 0.016 . The results support previous research, which found that learning achievement had no insignificant effect on student work-readiness [39]-[41]. Based on SCCT, career maturity mediates the impact of self-efficacy on career readiness. This finding is consistent with Bandura and Lent et al., which shows that selfefficacy can form outcome expectations [5], [42]. These findings are consistent with previous research, which states that values and beliefs support the assumption that adolescents value tasks where they think they can succeed [33], [43]. Therefore, a positive influence on selfefficacy has a close relationship with career readiness.

As hypothesized on $\mathrm{H} 4$, this study supports career maturity as a construct that mediates the effect of self-efficacy on career readiness. These findings are significant, with previous studies showing that the role of selfefficacy in increasing career readiness influences individual career maturity [44]. Formation of career readiness is effective if the education system is focused on research educational commercialization [45] and also on future professional competency development [46]. On the other hand, career maturity in this study has a partial role in increasing career readiness. In contrast to hypothesis 5, the role of career maturity as a mediator has different findings. It 
is probably since academic achievement is assessed based on subjectivity so that the output in the form of a grade point average (GPA) value obtained is not what it should be. For this reason, career maturity is limited as a predictor.

The survey respondents in this study were students with different family, ethnic, and religious backgrounds; besides, the finding was only based on students' views. On the other hand, in this study, an instrument developed for education was used so that the respondent could understand the measurement of career readiness outside the teaching profession. Thus, there is still room for investigating other variables using other instruments to determine student career readiness.

\section{CONCLUSION}

The results of this study add to the literature on career readiness by proving that self-efficacy and career maturity play an essential role in increasing career choice readiness. In contrast to academic achievement, it does not affect career readiness. Thus, based on this research and previous findings, the most significant step to improve career readiness is to increase self-efficacy and career maturity to face their future careers well. On the other hand, this study found that career maturity mediates partially on self-efficacy on career readiness. This study includes an investigation of the proposed mediation role with other factors that enhance student career readiness. The next research should carry out investigations regarding other vital factors that affect student career readiness. Also, further researchers should expand the sample and reveal the effectiveness of student career readiness.

\section{REFERENCES}

[1] J. O. Crites, "Career counseling: A comprehensive approach," Couns. Psychol., vol. 6, no. 3, pp. 2-12, 1976, doi: 10.1177/07399863870092005.

[2] A. Alhadabi and A. C. Karpinski, "Grit, self-efficacy, achievement orientation goals, and academic performance in University students," Int. J. Adolesc. Youth, vol. 25, no. 1, pp. 519-535, 2020, doi: 10.1080/02673843.2019.1679202.

[3] M. L. Savickas and E. J. Porfeli, "Career adapt-abilities scale: Construction, reliability, and measurement equivalence across 13 countries," J. Vocat. Behav., vol. 80 , no. 3, pp. 661-673, 2012, doi: 10.1016/j.jvb.2012.01.011.

[4] J. Vuori, P. Koivisto, P. Mutanen, M. Jokisaari, and K. Salmela-Aro, "Corrigendum to 'towards working life': Effects of an intervention on mental health and transition to post-basic education," J. Vocat. Behav., vol. 75, no. 2, pp. 237-238, 2009, doi: 10.1016/j.jvb.2009.05.009.

[5] R. Lent, S. D. Brown, and G. Hackett, "Toward a unifying SCCT and academic interest, choice and performance," $J$. Vocat. Behav., vol. 45, pp. 79-122, 1994, doi:

https://doi.org/10.1006/jvbe.1994.1027.

[6] T. T. York, C. Gibson, and S. Rankin, "Defining and measuring academic success," Pract. Assessment, Res. Eval., vol. 20, no. 5, pp. 1-20, 2015.

[7] J. Becherer, O. Köller, and F. Zimmermann, "Externalizing behaviour, task-focused behaviour, and academic achievement: An indirect relation?," $B r$. J. Educ. Psychol., pp. 1-19, 2020, doi: 10.1111/bjep.12347.

[8] P. Koivisto, A. D. Vinokur, and J. Vuori, "Effects of career choice intervention on components of career preparation," Career Dev. Q., vol. 59, no. 4, pp. 345366, 2011, doi: 10.1002/j.21610045.2011.tb00074.x.

[9] S. Kilminster, M. Zukas, N. Quinton, and T. Roberts, "Preparedness is not enough: Understanding transitions as critically intensive learning periods," Med. Educ., vol. 45, no. 10, pp. 1006-1015, 2011, doi: 10.1111/j.1365-2923.2011.04048.x. 
[10] M. L. Savickas, E. J. Porfeli, T. L. Hilton, and S. Savickas, "The student career construction inventory," J. Vocat. Behav., vol. 106, no. January, pp. 138-152, 2018, doi: 10.1016/j.jvb.2018.01.009.

[11] M. J. Miller, K. S. Roy, S. D. Brown, J. Thomas, and C. McDaniel, "A confirmatory test of the factor structure of the short form of the career decision selfefficacy scale," J. career Assess., vol. 17, no. 4, pp. 507-519, 2009, doi: https://doi.org/10.1177/10690727093406 65.

[12] S. Azwar, Tes Prestasi: Fungsi dan Pengukuran Prestasi Belajar. Yogyakarta: Pustaka Pelajar, 2013.

[13] G. D. Garson, Structural Equation Modeling. Asheboro, NC: Statistical Associates Publishers, 2015.

[14] Garson, Partial Least Squares: Regression and Structural Equation Models. Asheboro, NC: Statistical Associates Publishers, 2016.

[15] J. F. Hair, T. Hult, C. M. Ringle, and M. Starsted, A Primer on Partial Least Squares Path Modeling (PLS-SEM), 2nd ed. Thousand Oaks, CA: SAGE, 2017.

[16] C. M. Ringle, S. Wende, and J. M. Becker, "SmartPLS 3," 2015. .

[17] J. C. Sánchez-Prieto, F. Huang, S. Olmos-Migueláñez, F. J. García-Peñalvo, and T. Teo, "Exploring the unknown: The effect of resistance to change and attachment on mobile adoption among secondary pre-service teachers," $B r . J$. Educ. Technol., vol. 50, no. 5, pp. 24332449, 2019, doi: 10.1111/bjet.12822.

[18] J. F. Hair, J. W. C. Black, B. J. Babin, and R. E. Aderson, Multivarate Data Analysis. USA: British Library Cataloguing in Publication Data, 2014.

[19] E. Simangunsong, "Factors determining the quality management of higher education: A case study at a business school in Indonesia," Cakrawala Pendidik., vol. 38, no. 2, pp. 215-227,
2019, doi: 10.21831/cp.v38i2.19685.

[20] W. M. Long, Statistical Analysis Practice of Questionnaires: SPSS Operation and Application. Chongqing, China: Chongqing University Press, 2010.

[21] J. F. J. Hair, G. T. M. Hult, C. M. Ringle, and M. Sarstedt, A Primer on Partial Least Squares Structural Equation Modeling, Second edi. SAGE, 2017.

[22] N. P. Brataningrum and L. Saptono, "The influence of the effectiveness of accounting learning process on students' learning achievements," Cakrawala Pendidik., vol. 36, no. 3, pp. 342-356, 2017, doi: 10.21831/ cp.v36i3.14139.

[23] A. J. Setiyowati, M. Pali, B. B. Wiyono, and T. Triyono, "Structural model of counseling competence," Cakrawala Pendidik., vol. 38, no. 1, pp. 45-62, 2019, doi: 10.21831/cp.v38i1.21509.

[24] M. Tenenhaus and V. Esposito, "PLS path modeling," vol. 48, pp. 159-205, 2005, doi: 10.1016/j.csda.2004.03.005.

[25] M. Wetzels, G. Odekerken-Schroder, and C. van Oppen, "Using PLS path modeling for assessing hierarchical construct models: Guidelines and empirical illustration," MIS Q., vol. 33, no. 1, pp. 177-195, 2009, doi: 10.2307/20650284

[26] J. Henseler et al., "Common beliefs and reality about PLS: comments on Rönkkö and Evermann (2013)," Organ. Res. Methods, vol. 17, no. 2, pp. 182-209, 2014, doi: 10.1177/1094428114526928.

[27] N. Trisnawati, "Preparation for working readiness vocational education graduate with self-concept and self-efficacy development," J. Pendidik. Bisnis dan Manaj., vol. 3, no. 2, pp. 165-172, 2017, doi: 10.17977/um003v3i22017p165.

[28] Pujiyono, M. M. Minarsih, and A. T. Haryono, "Pengaruh effkacy kemampuan diri, kompetensi kerja dan motivasi kerja terhadap kesempatan kerja dengan placement tes sebagai variabel intervening," J. Manage., vol. 2, no. 2, 
pp. 1-30, 2016.

[29] A. Latif, A. M. Yusuf, and Z. M. Efendi, "Hubungan perencanaan karier dan efikasi diri dengan kesiapan kerja mahasiswa," Konselor, vol. 6, no. 1, p. 29, 2017, doi: 10.24036/02017616535-000 .

[30] A. Jones, M. E. Ingram, and R. Forbes, "Physiotherapy new graduate selfefficacy and readiness for interprofessional collaboration: A mixed methods study," J. Interprof. Care, pp. 1-10, 2020, doi: 10.1080/13561820.2020.1723508.

[31] S. Parikh-Foxx, R. Martinez, S. B. Baker, and J. Olsen, "Self-efficacy for enhancing students' career and college readiness: A survey of professional school counselors," J. Couns. Dev., vol. 98, no. 2, pp. 183-192, 2020, doi: 10.1002/jcad.12312.

[32] Y.-J. Ko and N. Kim, "Effect of career decision-making self-efficacy on career preparation behaviors mediated by career decision level," J. Digit. Converg., vol. 18, no. 4, pp. 301-308, 2020, doi: 10.14400/JDC.2020.18.4.301.

[33] J. S. Eccles and A. Wigfield, "Motivational beliefs, values, and goals," Annu. Rev. Psychol., vol. 53, no. 1, pp. 109-132, 2002, doi: Eccles, J. S., \& Wigfield, A. (2002). Motivational Beliefs, Values, and Goals. Annual Review of Psychology, 53(1), 109-132. doi:10.1146/annurev.psych.53.100901.1 35153 .

[34] E. Lestari and F. Tentama, "Students career maturity scale: Construct validity and reliability study," Int. J. Sci. Technol. Res., vol. 9, no. 1, pp. 480-485, 2020.

[35] R. A. Pratama and E. J. Sagala, "The influence of work readiness towards career development (study case of Telkom University diploma and bachelor graduates )," in e-Proceeding of Management, 2018, vol. 5, no. 2, pp. 2468-2473.
[36] R. Afriani and R. Setiyani, "Pengaruh persepsi siswa tentang kompetensi kejuruan, penguasaan soft skill, dan kematangan karir terhadap kesiapan kerja siswa kelas XII Akuntansi SMK Negeri 2 Magelang Tahun Ajaran 2014/2015," Econ. Educ. Anal. J., vol. 4, no. 2, pp. 453-468, 2015.

[37] M. Jawarneh, "Career maturity among university students in Jordan: The case for social studies," Aust. J. Career Dev., vol. 25 , no. 3 , pp. 110-116, 2016, doi: $10.1177 / 1038416216676807$.

[38] C. L. Caballero, A. Walker, and M. Fuller-Tyszkiewicz, "The work readiness scale (WRS): Developing a measure to assess work readiness in college graduates," J. Teach. Learn. Grad. Employab., vol. 2, no. 2, pp. 41-54, 2011, doi: 10.21153/jtlge2011vol2no1 art552.

[39] D. Triani and S. Arief, "Pengaruh praktik kerja industri, hasil belajar mata pelajaran akuntansi, dan motivasi memasuki kerja terhadap kesiapan kerja siswa akuntansi," Econ. Educ. Anal. J., vol. 5, no. 3, pp. 849-849, 2016.

[40] H. Ulfah, T. Kurniawati, and E. Cerya, "Pengaruh motivasi memasuki dunia kerja dan prestasi belajar terhadap kesiapan kerja mahasiswa pendidikan ekonomi fakultas ekonomi Universitas Negeri Padang," EcoGen, vol. 1, no. 2016, pp. 408-415, 2018.

[41] K. F. Andika, Basori, and A. Efendi, "Pengaruh keaktifan mahasiswa dalam organisasi dan prestasi belajar terhadap kesiapan kerja mahasiswa program studi pendidikan teknik informatika dan komputer Universitas Sebelas Maret Surakarta," J. Ilm. Pendidik. Tek. Kejuru., vol. 11, no. 2, pp. 69-78, 2018, doi: 10.20961/jiptek.v11i2.19570.

[42] A. Bandura, "Self-efficacy: Toward a unifying theory of behavioral change," Adv. Behav. Res. Ther., vol. 1, pp. 67-85, 1977, doi: $10.1017 / \mathrm{S} 0003055400259303$. 
[43] J. S. Eccles, M. N. Vida, and B. Barber, "The relation of early adolescents' college plans and both academic ability and task-value beliefs to subsequent college enrollment," J. Early Adolesc., vol. 24, no. 1, pp. 63-77, 2004, doi: $10.1177 / 0272431603260919$.

[44] S. Wasif, M. Sohail, and M. Nawab, "Significance of perceived social support for career decision self-efficacy: A corelational study," 2020, doi: 10.33897/fujp.v4i2.73.

[45] O. B. Kenzhaliyev, Z. B. Ilmaliyev, B. M. Triyono, A. D. Minghat, M. R. Arpentieva, and G. K. Kassymova, "Commercialization of research and development results as the economy growth factor of the Republic of Kazakhstan," Int. J. Adv. Sci. Technol., vol. 29, no. 7s, pp. 18-28, 2020, [Online]. Available: http://sersc.org/journals/index.php/IJAS T/article/view/9410.

[46] B. M. Triyono, N. Mohib, G. K. Kassymova, G. N. I. P. Pratama, D. Adinda, and M. R. Arpentieva, "The profile improvement of vocational school teachers' competencies," Vyss. Obraz. v Ross. = High. Educ. Russ., vol. 2, pp. 151-158, 29AD, doi: 10.31992/08693617-2020-29-2-151-158. 